by Ian W. Withnall ${ }^{1}$ and Robert A. Henderson ${ }^{2}$

\title{
Accretion on the long-lived continental margin of northeastern Australia
}

\author{
${ }^{1}$ Geological Survey of Queensland, Department of Natural Resources and Mines, PO Box 15216, City East, QLD 4002, Australia. E-mail: \\ ian.withnall@deedi.qld.gov.au \\ ${ }^{2}$ School of Earth and Environmental Sciences, James Cook University, Townsville, QLD 4811, Australia. E-mail: bob.henderson@ jcu.edu.au
}

The northern extremity of the late NeoproterozoicPaleozoic Tasman Orogenic zone exposed in north Queensland forms a narrow belt of tectonised rock assemblages abutting Paleoproterozoic-Mesoproterozoic rocks of the North Australian craton. The craton-orogen contact (Tasman Line) is extensively exposed, a unique circumstance for Australia. Sedimentary protoliths of the cratonic rocks were mainly deposited between 1700-1600 Ma and multiply deformed between 1600-1500 Ma. The Lynd Mylonite Zone, one expression of the Tasman Line, separates rocks of the late Neoproterozoic-Ordovician Thomson Orogen from those of the craton. The succeeding Silurian-Devonian Mossman Orogen is generally faulted against the Thomson Orogen, but in its northern extent it may directly abut the craton along the Palmerville Fault, also an expression of the Tasman Line. These two orogenic systems are dominantly of active margin association and E-stepping but deep seismic imaging indicates that they are extensively underlain by crust of Archean or Paleoproterozoic age. The Tasman Orogenic Zone in its southern part represents a broad tract of crust c. 1,000 km across, added to the cratonic core of Australia in a phase of rapid accretion. In contrast, for its north Queensland development a much smaller volume of new crust was generated, expressing slow accretion. For this region the orogenic system laps extensively onto cratonic crust, a geometry which at least in part reflects overthusting during episodes of Paleozoic contractional orogenesis. As a consequence of little orogenic accretionary outgrowth of the north Queensland continental margin, three large-scale, successive igneous assemblages of active margin association generated throughout the Paleozoic form largely co-located and overprinting belts with plutonic suites stitching the Tasman Line and extending into the craton.

\section{Introduction}

The boundary between Paleoproterozoic-Mesoproterozoic rocks of cratonic Australia and Paleozoic rock assemblages of the Tasman Orogenic Zone (Tasmanides) is well exposed in north Queensland (e.g., Shaw et al., 1987; Fergusson et al., 2007c). To the S, this boundary, the Tasman Line of Hill (1951) and subsequent authors, is obscured by Mesozoic cover and has been mapped by magnetic and gravity images. Some authors (e.g., Gunn et al., 1997; Scheibner and Veevers, 2000) have interpreted the boundary to mark Rodinian breakup along which crust now represented by Australia separated from that of Laurentia in the Neoproterozoic (Hoffman, 1991; Karlstrom et al., 2001; Gibson et al., 2008). However, others (e.g., Direen and Crawford, 2003) have suggested that a complex late Neoproterozoic-Carboniferous history produced a range of geophysical responses and have rejected the Tasman Line as marking continental rupture. New deep seismic data suggest that cratonic rocks in north Queensland extend E of the Tasman Line at least $150 \mathrm{~km}$ as a lower crustal layer beneath Paleozoic orogenic systems in the upper crust (Korsch et al., 2012).

Paleoproterozoic and Mesoproterozoic rock assemblages of north Queensland form part of the North Australian Craton (Figure 1). As noted by Austin and Foster (2008) and Cawood and Korsch (2008), assemblages of the Georgetown Inlier located in the East adjacent to the Tasman Line have a striking similar history to those of the Mount Isa Inlier in the W, suggesting that these tracts were conjoint by $1600 \mathrm{Ma}$. Substantial marine sedimentary basins were developed in both tracts between $1700-1600 \mathrm{Ma}$ with contactional orogenesis and plutonism between 1600-1550 Ma. Interpretation by Korsch et al. (2012) of two deep crustal suture zones imaged by seismic traversing, supported by magnetotelluric data, however, identifies episodes of Paleoproterozoic or older suturing involving crust of dissimilar origins.

The exposed north Queensland segment of the Tasmanides measures less than $300 \mathrm{~km}$ across compared to a span of c. 1,000 km for the coeval Lachlan Orogen in New South Wales and Victoria (Figure 1). It represents two sequential, E stepping orogenic systems expressed by voluminous igneous and sedimentary rock systems of continental margin association formed as belts over a specific interval of time and subsequently tectonised by discrete, intense episodes of contractional orogenesis. The inboard Thomson Orogen of Neoproterozoic-early Ordovician age, best represented by the Greenvale and Charters Towers provinces, is considered to be expansive in central and southern Queensland beneath Mesozoic cover (e.g., Betts et al., 2002; Glen, 2005). The outboard Silurian-Devonian 


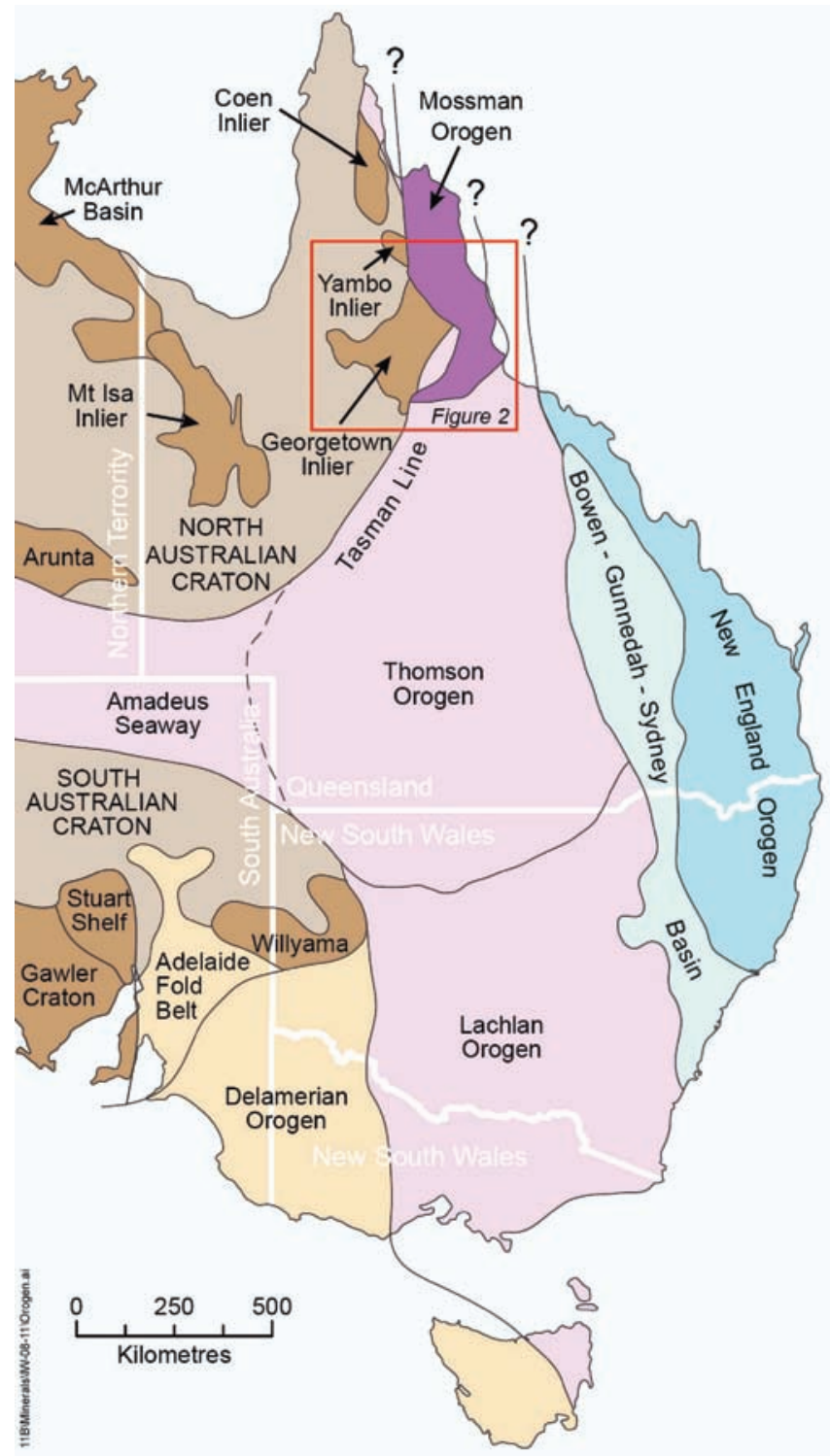

Figure 1 Eastern Australia, showing the main Proterozoic elements (outcropping parts shown in dark brown) and Paleozoic orogens.

Mossman Orogen, best represented by the Hodgkinson and Broken River provinces, terminates to the $\mathrm{S}$ on the Clarke River Fault Zone interpreted to be a sinistral strike-slip structure which has displaced southward continuation of the orogen offshore (Henderson, 1987, Henderson et al., 2011). The two orogenic systems have a meridional overlapping zone of contact considered in large part to consist of thrust dislocations. The New England Orogen, largely of Late Devonian-Permian age may form a third, easternmost orogenic belt in the region. It is mapped $\mathrm{N}$ along the coastal zone of central Queensland to Townsville where it passes offshore. Drill core records from the submerged Queensland Plateau (Mortimer et al., 2008) offshore from Cairns suggest it continues along the continental margin. late Carboniferous-Permian granitoids, hypabyssal suites including extensive dyke swarms and tracts of volcanics grouped as the Kennedy Igneous Association, considered to be related to the New England Orogen by Blevin et al. (1999), are widespread through the Thomson and Mossman orogenic belts extending $\mathrm{W}$ onto the craton.

In its southern expression, the Tasman Orogenic Zone is dominated by voluminous sedimentary systems associated with extensional tectonics (e.g., Foster and Gray, 2000; Kemp et al., 2009) shortened in a succession of contractional episodes, principally in the mid Silurian Benambran and Middle Devonian Tabberabberan orogenies (e.g., Glen, 2005). It its northern expression, extensional sedimentary systems of like scale are not in evidence but Benambran and Tabberabberan orogenesis applies, although the latter is offset in age to latest Devonian. Intrusions of two successive orogenic igneous belts, represented by the Siluro-Devonian Pama, and late Carboniferous-early Permian Kennedy Igneous Associations stitch the Tasman Line, a relationship which implies orogenic continental accretion of very limited scale. Deep seismic records have been interpreted as showing stacking of the Thomson and Mossman orogenic belts through large scale thrust transport (Korsch et al., 2012). Thus, as noted by Glen (2005), a major change in tectonic pattern from rapid to slow accretionary growth occurs along the Tasmanide belt between the Lachlan Orogen and north Queensland. The systematics of this shift and its underpinning mechanisms are presently unresolved.

This paper briefly reviews the nature of exposed crust in north Queensland (Figure 2) from the Precambrian craton to adjoining Paleozoic orogenic assemblages, in the broad context of crustal accretion along a long-lived continental margin. It probably first formed in the Neoproterozoic, although some authors (e.g., Betts and Giles, 2006) propose that it was a continental margin prior to the assembly of Rodinia. It was subject to active margin tectonics throughout the Paleozoic.

\section{Paleoproterozoic-Mesoproterozoic rocks}

Three inliers with Paleoproterozoic-Mesoproterozoic rocks adjoin the Tasman Line (Figure 1). Of these the Georgetown Inlier is the most extensive and best known. It consists mainly of Etheridge Province, a discrete stratotectonic rock assemblage which also extends along the eastern parts of the Yambo and Coen inliers. In the Georgetown Inlier, the metasedimentary Etheridge Group, the preserved part of a basinal succession at least $6 \mathrm{~km}$ thick, is extensively developed in its western parts where the intensity of deformation and metamorphism has not precluded stratigraphic documentation (see Figures 2 and 3).

The lower part of the Etheridge Group consists of fine-grained calcareous-dolomitic sandstone and siltstone-mudstone, overlain by locally pillowed metabasalt, passing up to carbonaceous mudstone, intruded by sills of Cobbold Metadolerite. The environment of deposition has been interpreted as an upward deepening package from near shore to deep marine (Withnall et al., 1997). The mafic rocks are relatively evolved, low-K, Fe-rich continental tholeiites (Baker et al., 2010). The upper part is variably carbonaceous siltstone and mudstone, with sandstone composed entirely of mudclasts. Gypsum casts are of sporadic occurrence. Parts of the succession have been interpreted as shallow water in a mud-dominated tidal flat environment (Withnall et al., 1997).

Recent SHRIMP zircon dating has provided constraints on the age of the Etheridge Group. The lower part is characterised by detrital zircon populations with a significant Archean to earliest Proterozoic component (up to 75\%), but with younger populations of 1850-1780 $\mathrm{Ma}$ and rare younger grains of c. $1695 \mathrm{Ma}$ (Neumann and Kositcin, 2011). A metabasalt has an age of $1663 \pm 13 \mathrm{Ma}$ (Baker et al., 2010) and a leucogabbro sill in the middle of the succession has a precise 


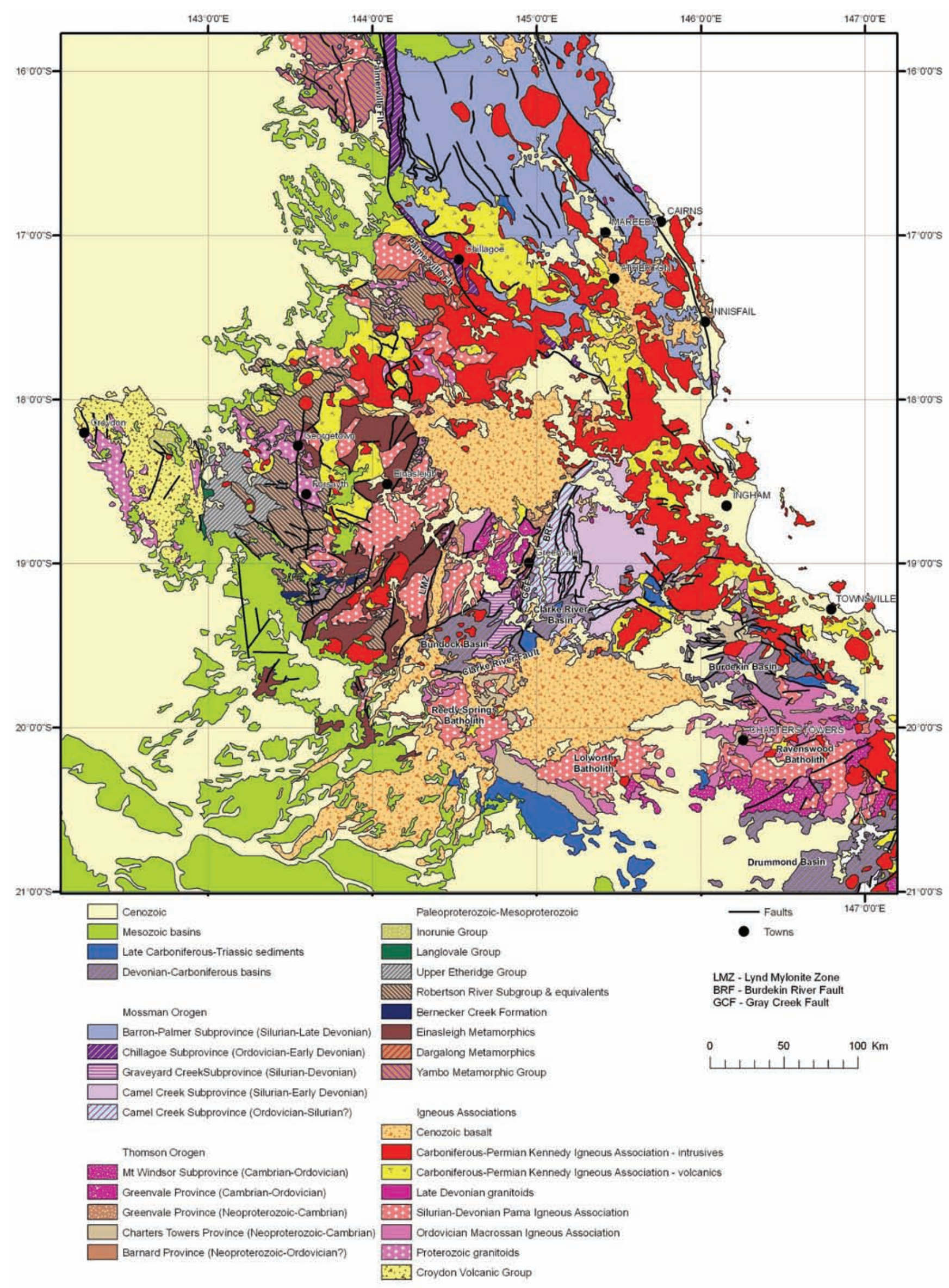

Figure 2 Generalised geology of north Queensland. 


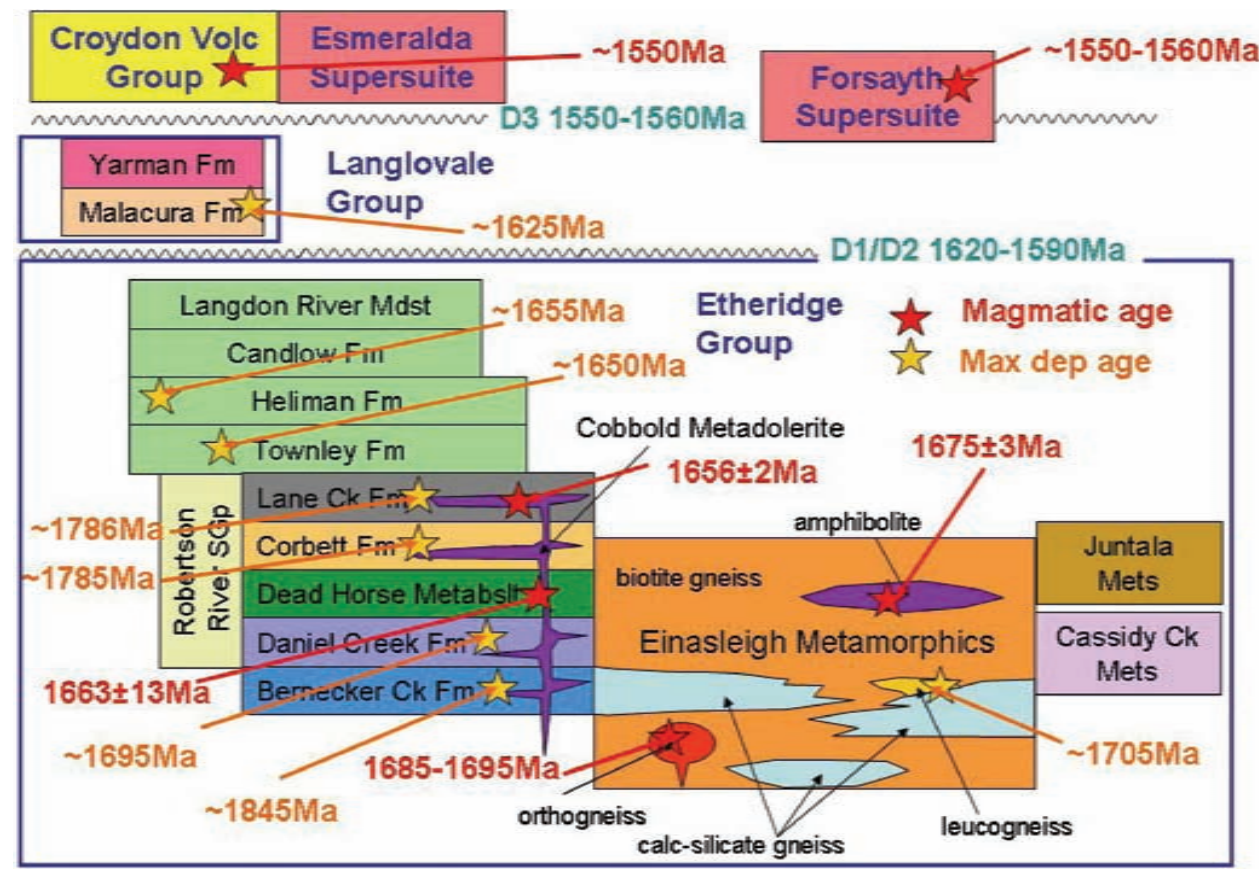

Figure 3 Temporal relationships for Proterozoic rocks in the Georgetown Inlier.

of the deformation increasing eastwards, along with metamorphic grade which increases from greenschist to local granulite facies. A province-wide deformation history is apparent from regional structural analysis and relationships (Withnall et al., 1997), zircon dating (Black et al., 1998, 2005), and microstructural studies combined with EPMA monazite dating (Cihan et al., 2006). N-S shortening $\left(D_{1}\right)$ of the Etheridge Province at c. $1620 \mathrm{Ma}$, prior to deposition of the Langlovale Group, was followed by E-W shortening $\left(\mathrm{D}_{2}\right)$ at c. $1590 \mathrm{Ma}$ accompanied by medium P-T metamorphism with uplift and retrogressive metamorphism between 1590-1560 Ma. NW-SE shortening $\left(\mathrm{D}_{3}\right)$ and low pressure-high temperature metamorphism at 1560-1550 Ma, was associated with general metamorphic zircon growth and emplacement of the S-type Forsayth Supersuite. This deformational episode predated

age of $1656 \pm 2 \mathrm{Ma}$ (Black et al., 1998). These data constrain the protolith age as between 1700-1655 Ma.

Detrital zircons from its upper part have greatly diminished Archean to earliest Proterozoic components and significant populations at c. 1655-1650 Ma (Neumann and Kositcin, 2011), indicating a major change in provenance. The host rocks also have relatively primitive $\varepsilon \mathrm{Nd}$ values compared with those from the lower Etheridge Group, which are more evolved (Lambeck, 2011).

In the eastern part of the Georgetown Inlier, the Einasleigh Metamorphics consist of biotite and calc-silicate paragneiss, common amphibolite and rare leucogneiss and orthogneiss considered to overlap the Etheridge Group in protolith age (Figure 3). Extensive areas of migmatite and anatectic granite also are present. The main age constraints are based on zircon dates from felsic leucogneiss, considered to represent feldspathic psammite, for which simple zircon populations suggesting a maximum depositional age of c. $1705 \mathrm{Ma}$ (Black et al., 2005). Rare granite gneisses give ages of 1695-1685 Ma (Black et al., 1998; Neumann and Kositcin, 2011). Amphibolite that cuts one of these gneisses has been dated at 1675 $\pm 3 \mathrm{Ma}$ (Black et al., 1998). The current data thus suggest deposition between c. 1700-1675 Ma.

The Langlovale Group unconformably overlies the Etheridge Group in the western Etheridge Province. It may be shallow marine in part but its but its upper part contains turbidites. Detrital zircon provides a maximum depositional age of c. $1625 \mathrm{Ma}$ (Neumann and Kositcin, 2011).

The unconformably overlying Croydon Volcanic Group consists of almost flat-lying sheets of unmetamorphosed felsic ignimbrite intruded by comagmatic granites of the Esmeralda Supersuite. They contain abundant graphitic enclaves - presumably derived from the Etheridge Group at depth. They are peraluminous, reduced and considered to be S-types, and have provided a multigrain TIMS U-Pb zircon age of $1552 \pm 2 \mathrm{Ma}$ (Black and McCulloch, 1990).

The Etheridge Group is multiply deformed with the complexity eruption of the Croydon Volcanic Group and emplacement of the Esmeralda Supersuite in the W at c. 1550 Ma.

\section{Neoproterozoic-Ordovician Thomson orogen}

A substantial part of NE Australia, lying between the Tasman Line and the New England Orogen but obscured by Mesozoic cover, is regarded as a distinctive crustal tract which developed in the Neoproterozoic and early Paleozoic (Figure 1). Over most of its distribution it is known only from gravity and magnetic trends and basement cores recovered from petroleum drilling. In the northern Tasmanides it is exposed as the Anakie, Charters Towers, Greenvale and Barnard provinces which adjoin the Mossman Orogen (Figures 2 and 4). The Anakie Province lies immediately to the $S$ of the area discussed in this paper and was described by Withnall et al. (1995) and Fergusson et al. (2001)

As presently understood, the Thomson Orogen is considered to consist of two elements (Fergusson et al., 2007a). Neoproterozoic to early Cambrian sedimentary systems and mafic igneous rocks formed on the passive margin along what is now eastern Australia following the breakup of Rodinia. This event is generally suggested as occurring at c. $700 \mathrm{Ma}$, although the abundance of rift-related magmatism of 600-570 Ma in eastern Australia led Crawford et al. (2003) to suggest that actual or renewed breakup began at c. $600 \mathrm{Ma}$. Delamerian contractional orogenesis followed, coincident with the inception of a convergent plate boundary located outboard of the east Australian margin. This older assemblage of the Thomson Orogen represents northward continuation of the Ross-Delamerian Orogen recognised for Antarctica and southern Australia. Rock assemblages of active margin association, including voluminous granitoids and volcano-sedimentary sequences developed in extensional basins, comprise the second element of the Thomson Orogen. Regional contraction during the mid Silurian Benambran Orogeny divides 


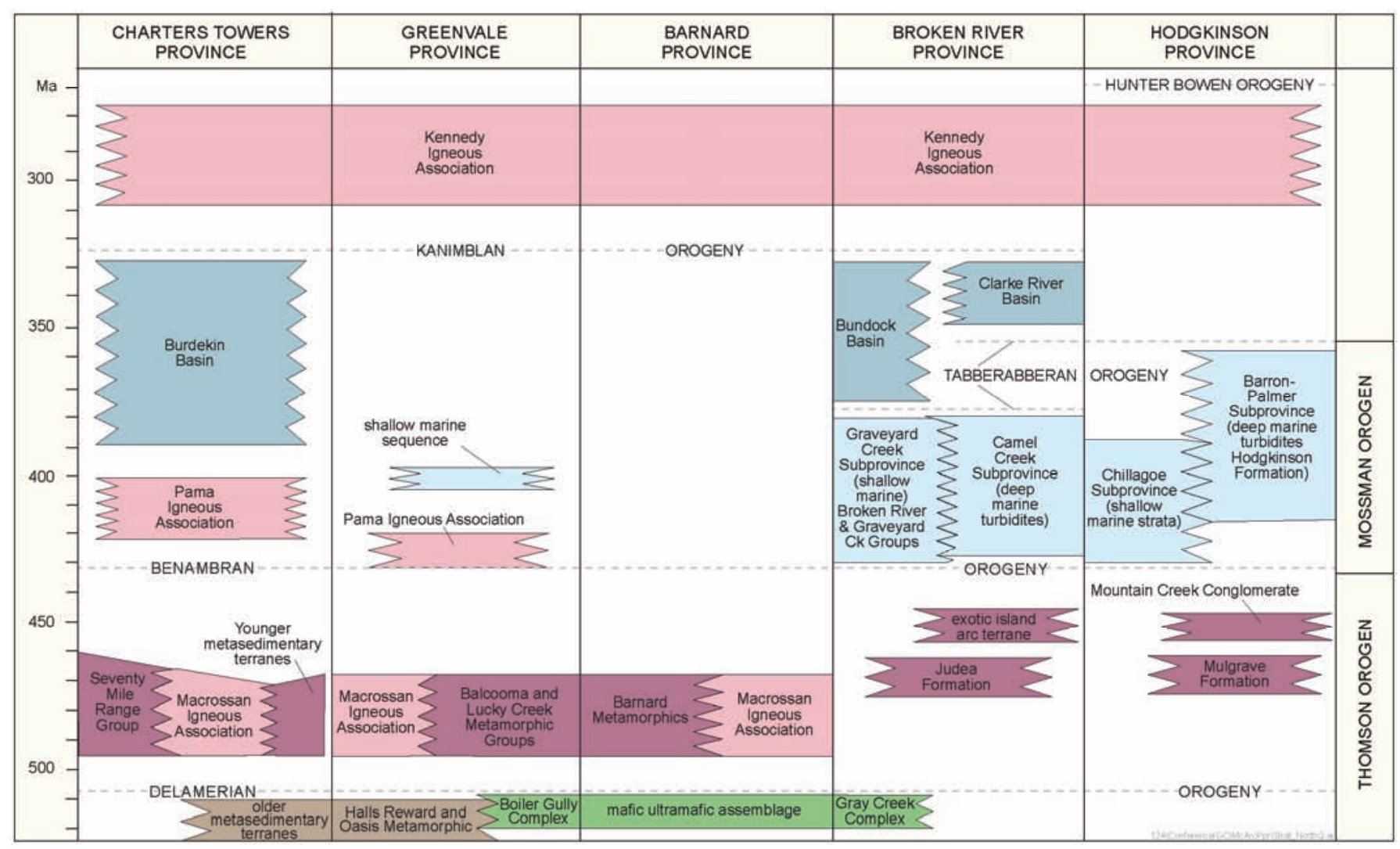

Figure 4 Temporal relationships for Paleozoic rocks in north Queensland.

Thomson orogenic assemblages from younger elements of the Tasmanides.

\section{Charters Towers Province}

Remnants of Neoproterozoic sedimentary systems, now tectonised as disparate metamorphic terranes which host and are separated by voluminous granitoids of the Ravenswood and Lolworth batholiths, are the oldest elements. Ordovician parts of the batholiths are of Thomson Orogen association. The province also contains tracts of variably, but in general lightly, deformed volcanic and sedimentary basin fill of latest Cambrian-Early Ordovician age, the Mount Windsor Subprovince. The late Paleozoic Burdekin Basin is local cover to rocks of the Thomson Orogen in the eastern part of the province.

Metamorphic rocks form discrete, widely scattered terranes separated by granitoids (Figure 2), and consisting largely of multiply deformed pelitic and psammitic schist, quartzite, calc-silicate rocks, amphibolite and rare serpentinite. Gneissic granitoid is a common associate. Detrital zircon ages obtained from meta-arenite and a zircon age from an igneous meta-breccia clast indicate that protoliths includes both Neoproterozoic and early Cambrian strata (Fergusson et al., 2005, 2007b). Diorite intruding the Charters Towers Metamorphics has a zircon age of $508 \mathrm{Ma}$ (Hutton et al., 1997).

Remnant foliations may record the late Cambrian Delamerian Orogeny, but are largely overprinted by an Early Ordovician episode of deformation that produced pervasive, shallowly dipping foliations accompanied by amphibolite grade metamorphism and considered to be extensional by Fergusson et al. (2007b). The dominant fabric is coplanar with that developed in granitic gneiss, emplacement of which is considered to be syntectonic. Zircon dates on the granitic gneiss are $493 \mathrm{Ma}$, whereas co-located, post-tectonic granitoid phases have ages of $461 \mathrm{Ma}$ and $455 \mathrm{Ma}$ (Hutton et al., 1997, Fergusson et al., 2007b). This extension is inferred to be the basin-forming mechanism related to deposition of protolith strata of the metamorphic terranes and to be coeval with basin development which accommodated the Seventy Mile Range Group volcano-sedimentary succession of like age. Late stage deformation of the metamorphic terranes involved upright folds and greenschist metamorphism dated by Ar/Ar as Silurian and considered to reflect Benambran orogenesis (Fergusson et al., 2005, 2007b).

The Seventy Mile Range Group is developed across the southern part of the Charters Towers Province (referred to as the Mount Windsor Subprovince) and represents the infill of an extensional basin, interpreted as a continental backarc feature (Henderson, 1986; Berry et al., 1992; Stolz, 1995). The base of the succession is stoped out by the Ravenswood Batholith and its upper part passes beneath younger cover. As preserved it has an apparent thickness of some $15 \mathrm{~km}$. Its lower part consists of siliciclastic deep marine strata and hosts tholeiitic mafic dykes of intraplate association. Its upper part consists of intermediate to silicic volcanic formations of deep marine facies (e.g., Monecke et al., 2006) and volcaniclastic strata with horizons containing an early Ordovician (Tremadocian-Darriwilian) pelagic fauna (Henderson, 1984). In general, strata of the group dip gently S but cleavage and upright folding is developed in its western distribution.

Batholiths of the Charters Towers Province are composites that include elements of the Ordovician Macrossan Igneous Association (490-455 Ma) allied to the Thomson Orogen, the Silurian-Devonian Pama Igneous Association (418-382 Ma) allied to the Mossman 
Orogen, and the late Carboniferous-early Permian Kennedy Igneous Association allied to the New England Orogen for which volcanic and sub-volcanic rocks are also represented. Hornblende and/or biotite bearing I-type granitoids dominate the Macrossan Igneous Association. They show persistent evidence of strain with common incipient fabric development and are cut by local shear zones with intense fabrics (Hutton et al., 1997).

The Burdekin Basin is nonconformable on crystalline rocks of the Thomson Orogen. It contains a Middle Devonian-early Carboniferous sedimentary and volcanic succession up to $6 \mathrm{~km}$ thick (Draper and Lang, 1994). It is mainly non-marine apart from the shallow marine basal part and later short-lived marine incursions. The basin fill shows broad, open folds of variable orientation and is cut by common faults, many of which have substantial displacements. It is considered to be of backarc, extensional association and is coeval with rocks of the Mossman Orogen to which it is allied. Basin inversion predates the emplacement of Permian plutons of the Kennedy Igneous Association and is thought to have occurred in the late Carboniferous, as part of the Kanimblan Orogeny which is widely recognised in eastern Australia.

\section{Greenvale Province}

This part of the Thomson Orogen consists of a NE-trending domain of predominantly late Neoproterozoic-early Paleozoic sedimentary and igneous rocks now metamorphosed to greenschist or amphibolite grade (Withnall, 1989; Fergusson et al., 2007c). It adjoins the Paleoproterozoic-Mesoproterozoic Etheridge Province along a major dislocation marked by the Lynd Mylonite Zone (Figure 2), now recognised as the Tasman Line.

In the westernmost part of the province, paragneiss and amphibolite assigned to the Oasis Metamorphics are intruded by gneissic granitoid that can be equated to the Macrossan Igneous Association. The age of metamorphic rims to zircon in gneiss dates the dominant fabric as c. $475 \mathrm{Ma}$, and cores suggest a Neoproterozoic or Cambrian depositional age. A primary age of c. 485 Ma has been obtained from gneissic granitoid hosted by the metasedimentary suite (Fergusson et al., 2007c).

Between the Balcooma Mylonite Zone in the W and the NEtrending early Silurian Dido Batholith (Pama Igneous Association) in the $\mathrm{E}$, the metavolcanic and metasedimentary succession of the Early Ordovician Balcooma Metavolcanic Group is of similar content to the Seventy Mile Range Group of the Charters Towers Province. Geochronological constraints indicate that the two sequences are broadly coeval (Huston, 1990; Withnall, 1989; Withnall et al., 1991, 1997). East of the Dido Tonalite, a second metavolcanic assemblage, the Lucky Creek Metamorphic Group is probably also of early Paleozoic age. It contains mafic-silicic volcanic and volcaniclastic rocks (Withnall, 1989), but its eastern part is dominantly metapelite.

The early Paleozoic domains have an intense early foliation/ cleavage considered to have been of low dip when formed and subsequently steepened by up to two overprinting folding and cleavage events (Fergusson et al., 2007c). Protolith of the metasedimentary assemblage is interpreted to be the floor of an extensional basin, tectonised by continuation of the strain regime which sponsored extension. Overprinting upright cleavage and folding events are probably an expression of the Silurian Benambran Orogeny. Rare outliers of gently dipping, unstrained, Early Devonian marine rocks unconformably on the early Paleozoic metasedimentary and metavolcanic rocks (Withnall, 1989; Withnall and Lang, 1993). The Dido Batholith, dated as early Silurian (c. $430 \mathrm{Ma}$ ) shows strong local subvertical foliation (Withnall et al., 1997) consistent with synBenambran emplacement.

A metasedimentary tract (Halls Reward Metamorphics) with a Neoproterozoic or early Cambrian protolith age and associated with mafic-ultramafic rocks (Boiler Gully Complex) forms an eastern bounding strip to the province. It was deformed in the middle Cambrian (520-500 Ma; Nishiya et al., 2003). Deep seismic imaging shows a positive culmination in upper crustal structure coincident with outcrop of the Halls Reward Metamorphics (Korsch et al., 2012).

\section{Barnard Province}

The Barnard Province (Figure 2) consists of multiply deformed schist, quartzite, gneiss, amphibolite, metamorphosed ultramafic rocks and granitoids. It occupies a narrow coastal strip extending from Mission Beach to E of Cairns. Strongly foliated S-type granitoid and less deformed felsic I-type granitoid were dated by SHRIMP at 486 and $463 \mathrm{Ma}$, respectively (Bultitude et al., 1997). The assemblage resembles metamorphic and plutonic suites of the Thomson Orogen represented in the Charters Towers Province.

\section{Silurian-Devonian Mossman Orogen}

The Mossman Orogen is located in the coastal sector of north Queensland, embracing the Broken River and Hodgkinson provinces, which are separated by tracts of late Paleozoic igneous rocks. Its sedimentary assemblages abut those of the Thomson Orogen and the north Australian craton. A belt of Silurian-Devonian granitoids (Pama Igneous Association) hosted by older rock systems to the $\mathrm{S}$ and $\mathrm{W}$ are also assigned to the orogen (Figures 2 and 4). These rocks have been variously interpreted as a coeval magmatic arc (Henderson 1987; Henderson et al., 2011), and as a zone of magmatic underplating related to backarc extension (Bultitude et al., 1997).

Although tectonic interpretation remains contentious, the orogen is regarded as an active continental margin assemblage that formed adjacent to a plate boundary where W-directed subduction transported oceanic crust beneath the continental edge of Australia. Both backarc and forearc/accretionary wedge models have been applied in rationalising its tectonic setting (Arnold and Fawckner, 1980; Henderson, 1987; Withnall and Lang, 1993; Henderson et al., 2011). Deposition was terminated and the orogen was comprehensively tectonised by crustal shortening in the Late Devonian, broadly correlated with the Tabberabberan Orogeny of the Lachlan Orogen. Much of the Hodgkinson Province was later shortened by the late Paleozoic-Triassic Hunter-Bowen Orogeny (Davis et al., 2002) which is best known from the New England Orogen.

\section{Broken River Province}

Two contrasting, spatially discrete assemblages are recognised. In the E, an Ordovician-Early Devonian, strongly tectonised assemblage of deep marine turbidites and local basalt and chert form the Camel Creek Subprovince. The smaller Graveyard Creek Subprovince in the SW consists largely of a thick, less deformed succession of marine to terrestrial late Silurian-early Carboniferous strata (Withnall and Lang, 1993). Rocks of the two subprovinces are separated by the Gray Creek Fault (Figure 2). The province is 
terminated in the S against the Clarke River Fault. Major dislocation on this structure in the Late Devonian juxtaposed the mid Paleozoic rocks of the Broken River Province against older assemblages of the Charters Towers Province. The western boundary is marked by the Burdekin River Fault.

\section{Graveyard Creek Subprovince}

A basement assemblage of Thomson Orogen located immediately to the W of the Gray Creek Fault, and also as inliers in anticlinal cores, consists of a variably deformed and serpentinised maficultramafic assemblage (Gray Creek Complex) of probable Cambrian age and cleaved quartzose turbidites and associated bimodal lavas of the Early Ordovician Judea Formation, both cut by small Ordovician tonalitic intrusions.

An angular unconformity separates this assemblage from an $8 \mathrm{~km}$ thick early Silurian-Late Devonian sedimentary succession. The Silurian section (Graveyard Creek Group) commenced with conglomerate up to $500 \mathrm{~m}$ thick and largely derived from the underlying basement, passing up into deep marine strata, locally volcaniclastic towards the base, and closing with shallow marine limestone. The Devonian succession (Broken River Group) is typified by shallow marine limestone subject to tight biostratigraphic control (Withnall and Lang, 1993; Talent et al., 2002).

Frasnian contraction, marking the terminal event in the Mossman Orogen, is registered in the Graveyard Creek Subprovince by a low angle unconformity of short duration in its western part. The succeeding Famennian-Visean Bundock Basin has some $7 \mathrm{~km}$ of infill. Its succession is largely fluviatile and commonly volcaniclastic, but has several shallow marine intercalations. Conglomerates in the lower part are derived largely from Camel Creek sandstones and jasper. In the eastern part of the subprovince, late Devonian contraction induced folding and inversion of Silurian and Devonian strata and major movement on the Clarke River Fault truncating the Mossman Orogen occurred at this time.

The Middle Devonian-Frasnian successions of the Graveyard Creek Subprovince are closely comparable to their correlatives in the Burdekin Basin of the Charters Towers Province. This relationship implies that they formed in closer proximity than that now shown, consistent with later separation by sinistral displacement on the Clarke River Fault (Henderson, 1987).

A younger, late Carboniferous contraction, assigned to the Kanimblan Orogeny, was the main deformation in the Graveyard Creek Subprovince. It produced broad scale, upright, NE-trending folds and high angle thrust faults.

\section{Camel Creek Subprovince}

Several assemblages of sedimentary and volcanic rocks are recognised for the subprovince, but superpositional relationships have been prejudiced by widespread mélange development and faulting. Few fossils are known and age control is poor.

The westernmost assemblage is a distinctive, fault bounded and internally disrupted association of generally quartz-poor siliciclastic rocks, shallow marine fossiliferous limestone and predominantly mafic to intermediate volcanic rocks considered to be an exotic oceanic island arc terrane (Henderson et al., 2011). Corals and conodonts from the limestones indicate a Late Ordovician age (Withnall and Lang, 1993). Henderson et al. (2011) considered the assemblage to represent oceanic crust accreted during Benambran orogenesis.

Most of the subprovince consists of contrasting belts of lithofeldspathic and quartz-rich turbidite units, which locally include chert and basalt (Withnall and Lang 1993). Redeposited conglomerate, sporadically with limestone clasts, is represented in some lithofeldspathic units as are blocks of limestone, some several kilometres long, which are considered allochthonous (Sloan et al., 1995). Fossils from limestone are of Silurian and early Devonian age. The age of quartz-rich units is unknown and they could represent dismembered parts of the Thomson Orogen which deep seismic profiling suggests is extensively developed at depth in the crust (Korsch et al., 2012). Persistent westerly facing for individual beds is in opposition to the sparse age information which indicates an overall age progression from older strata in the $\mathrm{W}$ to younger in the E.

The turbidite assemblage was extensively deformed by mélange formation and by local folding in the early stages of lithification. Tight, asymmetric meso-scale folding with western limbs dominant and the imposition of a weak but very widespread slaty cleavage represents a succeeding event. Folds are characteristically steeply plunging. The folds trend NNE-SSW in the W but ENE-WSW in the SE, having been refolded, along with the cleavage, by a broad oroclinal bending with a NE-trending axial trace. This assemblage was weakly metamorphosed to sub-greenschist facies. Small syntectonic granitoid bodies hosted by the sedimentary assemblage are dated by K-Ar at 357 Ma (Withnall and Lang, 1993).

Such tectonism occurred prior to inception of the Late DevonianCarboniferous (Famennian-Visean) Clarke River Basin which contains a succession, up to $1,500 \mathrm{~m}$ thick that is mainly fluviatile, but is sporadically shallow marine near the base, and becomes markedly volcaniclastic towards the top. It is coeval with, and of like character, to the Bundock Basin of the Graveyard Creek Subprovince. A final NE-SW trending fold phase in the Camel Creek Subprovince, representing Kanimblan orogenesis, is expressed by low to intermediate dips in the Clarke River Group.

\section{Hodgkinson Province}

This element trends northwards and is bounded to the W by the Palmerville Fault. It contains two contrasting sedimentary tracts: the Chillagoe Subprovince, a narrow western sector characterised by limestone and basalt and segmented by intense faulting; and the Barron-Palmer Subprovince, a pervasively tectonised terrane of deep marine turbidites and subordinate basalt and chert (Bultitude et al., 1993, 1997). It has a metamorphic overprint which ranges from subgreenschist in the $\mathrm{W}$ to upper greenschist (biotite zone) in the $\mathrm{E}$.

\section{Chillagoe Subprovince}

The element is less than $20 \mathrm{~km}$ across but extends along strike for over $150 \mathrm{~km}$. Abutting the Palmerville Fault, a narrow belt of siliciclastic rocks affiliated with assemblages of the Thomson Orogen consists of quartzose turbidites with subordinate mudstone, chert and basalt (Mulgrave Formation) in fault contact with massive volcaniclastic conglomerate containing limestone lenses (Mountain Creek Conglomerate). A zircon date obtained from a dacite clast and conodonts from limestone provided a Late Ordovician age (Bultitude et al., 1993). 
The main assemblage (Chillagoe Formation) consists of shallow marine limestone, chert, arenite, pelite, conglomerate and basalt, disrupted by intense thrust repetition. Corals and conodonts indicate ages from mid Silurian to late Early Devonian for limestone (Bultitude et al., 1993, 1997). The belt has extraordinary structure with strata dipping steeply E but facing to the W and thus overturned.

\section{Barron-Palmer Subprovince}

Quartz-intermediate turbidites, commonly disrupted by mélange, dominate this subprovince, but basalt, chert, redeposited conglomerate and rare limestone bodies are also represented. No broad-scale lithological discrimination has proven possible and the entire assemblage has been mapped as Hodgkinson Formation. Corals and conodonts from limestone range from Silurian-Late Devonian (Famennian), but widespread plant macrofossils confirm that a significant part is Middle-Late Devonian.

Small tracts of late Carboniferous and Permian sedimentary cover successions are present. Most are little disturbed, but they are folded and cleaved in the $\mathrm{E}$.

Structure of the Hodgkinson Formation shows a consistent, regional pattern. Ubiquitous mélange is an early phase and an early fabric $\left(\mathrm{S}_{1}\right)$ coplanar with bedding is also widely developed. Tight folding at both meso- and large-scale, with the generation of an incipient to intense cleavage $\left(\mathrm{S}_{2}\right)$ is characteristic of the Hodgkinson Formation throughout its distribution. It is dated at c. 355-360 Ma based on the age of syntectonic Mount Formartine Granite, and is only slightly younger than the Late Devonian age of the youngest

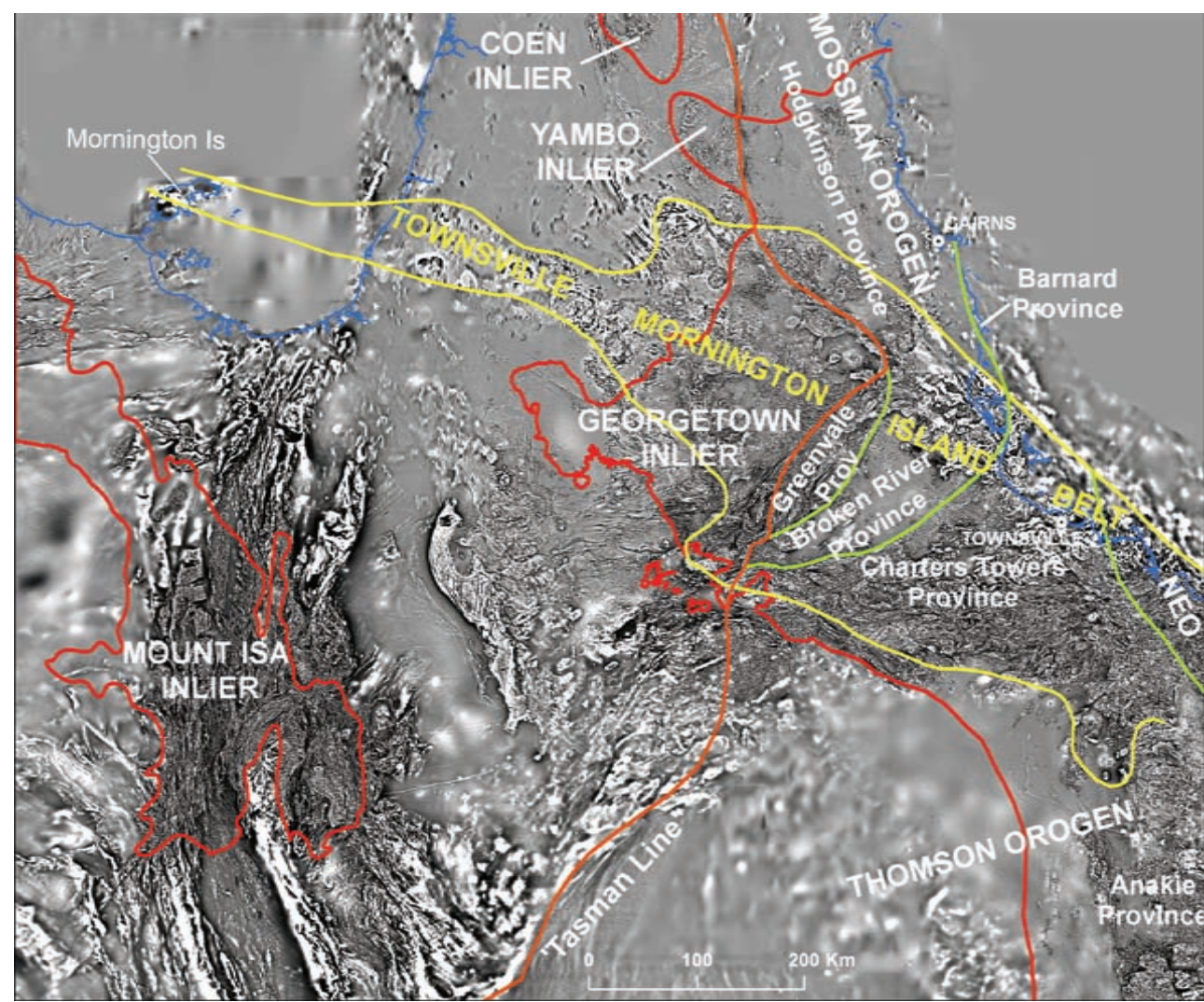

Figure 5 First-vertical-derivative magnetic image for north Queensland showing the main structural elements and the Townsville-Mornington Island belt (yellow). The cratonic margin (Tasman Line) is delineated in orange, and the red line shows the limits of exposure of pre-Mesozoic rocks. rocks it affects (Zucchetto et al., 1999). Thrust faulting in the Chillagoe Subprovince predates Carboniferous plutonism. An overprinting shallowly inclined $\mathrm{S}_{3}$ fabric and associated folds sporadically developed in the Barron-Palmer Subprovince are interpreted as extensional structures and considered to be early Permian (Davis and Henderson, 1999; Davis et al., 2002). A final deformational episode is widely expressed across the subprovince, particularly in the $\mathrm{E}$, and is represented by the development of $\mathrm{S}_{4}$ cleavage and associated mesoscopic folds that are coaxial with $\mathrm{D}_{2}$. Dated syntectonic plutons indicate that the commencement of $\mathrm{D}_{4}$ shortening was also early Permian and only slightly offset in time from $\mathrm{D}_{3}$.

\section{Kennedy igneous association}

The term Kennedy Province was coined by Bain and Draper (1997) for Carboniferous-Permian (c. 340-270 Ma) igneous rocks that extend throughout north Queensland. It is here referred to as the Kennedy Igneous Association.

In the area discussed in this paper, the rocks are concentrated in the Townsville-Mornington Island Belt (TMIB) (Figure 5), cropping out in a W-NW-trending band $(800 \times 300 \mathrm{~km})$ that transgress all of the older provinces. Concealed rocks of the same geophysical character extend at least $300 \mathrm{~km}$ farther WNW to the coast of the Gulf of Carpentaria. Early Permian granite has been intersected by drilling on Mornington Island, a further $200 \mathrm{~km}$ to the W.

The TMIB includes major batholiths, smaller intrusions and numerous major volcanic fields. Most of these volcanic fields are preserved in large composite cauldron complexes, and are dominated by thick piles of dacitic-rhyolitic ignimbrite and some lavas with subordinate mafic lavas (Withnall et al., 1997; Bultitude et al., 1997; Mackenzie and Wellman, 1997).

The rocks are little disturbed by tectonism. Granitic intrusions are geochemically diverse, including S, I and A types. Two age clusters are represented: end-of-Devonian-early Carboniferous (357-335 Ma) and late Carboniferous-Permian (305-270 Ma). Basic-silicic dykes are widely represented, locally as swarms. The wide spread of magmatism in both space and time indicates broad-scale heterogeneous thermal input, or a series of inputs, over a period of 70 Myr.

The magmatic rocks are coeval with and merge southwards into late Paleozoic volcanic and plutonic rocks in the New England Orogen which are generally thought to have formed on an Andean margin related to a westerly dipping subduction zone. Carboniferous forearc and accretionary wedge assemblages are recognised in the $\mathrm{E}$ of the New England Orogen, although they are not evident for the Permian component, which shows some evidence for crustal thinning and 
transition to an extensional setting (Withnall et al., 2009). Most early models for the tectonic setting and origin of the rocks of the Kennedy Igneous Association also proposed a subduction-related setting (e.g., Henderson, 1980; Bailey et al., 1982). However, major caldera-related volcanic fields elsewhere in the world are clearly in extensional settings: e.g., southwestern USA (extension over a subducted spreading ridge), Taupo Volcanic Field, northern Turkey and parts of the Andes (backarc extension in continental crust). Oversby and Mackenzie (1995) interpreted the Carboniferous and early Permian volcanics in the Georgetown region in terms of E-W (Carboniferous) and subsequent (early Permian) NE-SW extension. Mackenzie and Wellman (1997) proposed that the Kennedy Province was essentially the result of crustal melting in an extensional (or transtensional), possibly backarc, tectonic environment. However, the reasons for the change of tectonic setting and trend of the rocks of the Kennedy Igneous Association compared with coeval magmatic rocks in the New England Orogen and their geodynamic linkages have yet to be satisfactorily explained.

\section{Discussion}

Cratonic crust $\mathrm{W}$ of the Tasman line, as represented by adjacent Precambrian inliers, had no substantive addition through basin formation in the Neoproterozoic and Paleozoic. For the Thomson Orogen, older, pre-late Cambrian rocks are consistent with a passive margin origin but their contribution to surface exposure is very small. The more conspicuous late Cambrian-Ordovician assemblages with a strong plutonic and calc-alkaline volcanic representation, maficultramafic rocks and sedimentary suites of deep marine character have the hallmarks of an active continental margin association. However they are generally of inboard, arc or backarc affiliation with potential outboard suites conspicuously under-represented. Representatives of the succeeding plutonic suites of the Siluro-Devonian Pama and late Carboniferous-Permian Kennedy Igneous associations, also of active margin association, are hosted by the Thomson Orogen and also by the craton implying very limited outward stepping of the continental margin by crustal accretion through the Neoproterozoic and early Paleozoic.

An ongoing active margin setting is apparent for the Mossman Orogen. The pairing of inboard shallow marine Silurian-Devonian successions (Graveyard Creek and Chillagoe Subprovinces) with outboard, broadly coeval, strongly deformed, deep marine turbiditefacies sedimentary belts has led some workers to advocate a forearcaccretionary prism model for their setting (e.g., Arnold in Arnold and Fawckner, 1980; Cooper et al., 1975; Henderson, 1987; Henderson et al., 2011). Others have suggested a backarc model (e.g., Fawckner in Arnold and Fawckner 1980; Bultitude et al., 1993 1997; Withnall and Lang, 1993). Regardless of interpretation, the Graveyard Creek and Chillagoe Subprovinces are disjunct, with their continuity broken by fault juxtaposition of the Camel Creek Subprovince against those of the Thomson Orogen. Substantial lateral transport by overthrusting across the shallow marine on this fault contact is implied.

Interpretation of deep seismic imaging by Korsch et al. (2012) suggests that shortening by very large scale thrust imbrications, induced by contractions of the Benambran and Tabberabberan orogenies, have been formative for the upper crustal architecture of the northern Tasmanides. The original palinspastic patterns of the Thomson and Mossman orogens have been severely disrupted by shortening, with very limited outward growth of the continental margin. Successive episodes of active margin melt generation were emplaced along zones of similar location.

Although a contractional setting is evident for the late Paleozoic of the New England Orogen to the S, this is not evident for the coeval Kennedy Igneous Association in north Queensland, which is transverse to the continental margin and appears to be related to an extensional or transtensional setting.

\section{Acknowledgements}

This paper benefited from thorough reviews by Russell Korsch and Dick Glen. It is published with the permission of the General Manager, Geological Survey of Queensland.

\section{References}

Arnold, G.O. and Fawckner, J.F., 1980, The Broken River and Hodgkinson Provinces, in Henderson, R.A. and Stephenson, P.J. (eds), The Geology and Geophysics of Northeastern Australia: Geological Society of Australia Inc., Queensland Division, Brisbane, pp. 175-189.

Austin, J.R. and Foster, D.R.W., 2008, The 1800-1610 stratigraphic and magmatic history of the Eastern Succession, Mount Isa Inlier and correlations with adjacent Paleoproterozoic terranes: Precambrian Research, v. 163, pp. 7-30.

Bailey, J.C., Morgan, W.R. and Black, L.P., 1982, Geochemical and isotopic evidence for the age, orogenic setting and petrogenesis of the Nychum volcanic association, North Queensland: Journal of the Geological Society of Australia, v. 29, pp. 375-393.

Bain, J.H.C. and Draper, J.J. (eds), 1997, North Queensland Geology: Australian Geological Survey Organisation Bulletin 240/Queensland Geology 9.

Baker, M.J., Crawford, A.J. and Withnall, I.W., 2010, Geochemical, Sm-Nd isotopic characteristics and petrogenesis of Paleoproterozoic mafic rocks from the Georgetown Inlier, north Queensland: Implications for relationship with the Broken Hill and Mount Isa Eastern Succession: Precambrian Research, v. 17, pp. 39-54.

Berry, R.F., Huston D.L., Stolz A.J., Hill A.J., Beams S.D., Kuronen U. and Taube, A., 1992, Stratigraphy, structure and volcanic-hosted mineralization of the Mount Windsor Subprovince, north Queensland, Australia: Economic Geology, v. 87, pp. 739-763.

Betts, P.G. and Giles, D., 2006, The 1800-1100 Ma tectonic evolution of Australia: Precambrian Research, v. 144, pp. 92-125.

Betts, P.G., Giles, D., Lister, G.S. and Frick, L.R., 2002, Evolution of the Australian lithosphere: Australian Journal of Earth Sciences, v. 49, pp. 661-695.

Black, L.P. and McCulloch, M.T., 1990, Isotopic evidence for the dependence of recurrent felsic magmatism on new crust formation: Geochimica et Cosmochimica Acta, v. 54, pp. 49-60.

Black, L.P., Gregory, P., Withnall, I.W. and Bain, J.H.C., 1998, U-Pb zircon age for the Etheridge Group, Georgetown region, north Queensland: implications for relationship with the Broken Hill and Mt Isa sequences: Australian Journal of Earth Sciences, v. 45, pp. 925-935.

Black, L.P., Withnall, I.W., Gregory, P., Oversby, B.S. and Bain, J.H.C., 2005, $\mathrm{U}-\mathrm{Pb}$ zircon ages from leucogneiss in the Etheridge Group and their significance for the early history of the Georgetown region, north Queensland: Australian Journal of Earth Sciences, v. 52, pp. 385-401.

Blevin, P.L., Allen, C.M. and Chappell, B.W., 1999, Permo-Carboniferous magmatism in north Queensland: where does New England end? in Flood P.G. (ed), New England Orogen; Regional Geology, Tectonics and Metallogenesis: University of New England, Armidale, pp. 297-299.

Bultitude, R.J., Donchak, P.J.T., Domagala, J. and Fordham, B.G., 1993, The Pre-Mesozoic stratigraphy and structure of the western Hodgkinson Province and environs. Queensland Geological Record 1993/29. 
Bultitude, R.J., Garrad, P.D., Donchak, P.J.T., Domagala, J., Champion, D.C., Rees, I.D., Mackenzie, D.E., Wellman, P., Knutson, J., Fanning, C.M., Fordham, B.G., Grimes, K.G., Oversby, B.S., Rienks, I.P., Stephenson, P.J., Chappell, B.W., Pain, C.F., Wilford, J.R., Rigby, J.F. and Woodbury, M.J., 1997, Cairns Region, in Bain, J.H.C. and Draper, J.J. (eds), North Queensland Geology: Australian Geological Survey Organisation Bulletin 240/Queensland Geology 9, pp. 225-325.

Cawood, P.A. and Korsch, R.J., 2008, Assembling Australia. Proterozoic building of a continent: Precambrian Research, v. 166, pp. 1-38.

Cihan, M., Evins, P., Lisowiec, N. and Blake, K., 2006, Time constraints on deformation and metamorphism from EPMA dating of monazite in the Proterozoic Robertson River Metamorphics, NE Australia: Precambrian Research, v. 145, pp. 1-23

Cooper, J.A., Webb, A.W. and Whitaker, W.G., 1975, Isotopic measurements in the Cape York peninsula area, north Queensland: Journal of the Geological Society of Australia, v. 22, pp. 285-310.

Crawford, A.J., Meffre, S. and Symonds, P.A., 2003, 120 to 0 Ma tectonic evolution of the southwest Pacific and analogous evolution of the 600220 Ma Tasman Fold Belt System, in Hillis, R.R. and Müller, R.D. (eds), Evolution and Dynamics of the Australian Plate: Geological Society of Australia, Special Publication 22 and Geological Society of America, Special Paper 372, pp. 383-403.

Davis, B.K. and Henderson, R.A., 1999, Syn-orogenic extensional and contractional deformation related to the granite emplacement in the northern Tasman Orogenic Zone, Australia: Tectonophysics, v. 305, pp. 453-475.

Davis, B.K., Bell, C.C., Lindsay, M. and Henderson, R.A., 2002, A single late orogenic Permian episode of gold mineralisation in the Hodgkinson Province, north Queensland: Economic Geology, v. 97, pp. 311-322.

Direen, N.G. and Crawford, A.J., 2003, The Tasman Line: where is it, what is it, and is it Australia's Rodinian breakup boundary? Australian Journal of Earth Sciences, v. 50, pp. 491-502.

Draper, J.J. and Lang, S.C., 1994, Geology of the Devonian to Carboniferous Burdekin Basin: Queensland Geological Record 1994/9.

Fergusson, C.L, Carr, P.F., Fanning, C.M. and Green, T.J., 2001, Proterozoic-Cambrian detrital zircon and monazite ages from the Anakie Inlier, central. Queensland: Grenville and Pacific-Gondwana signatures: Australian Journal of Earth Sciences, v. 48, pp. 857-866.

Fergusson, C. L., Henderson, R. A., Lewthwaite, K. J., Phillips, D. and Withnall, I. W., 2005, Structure of the Early Palaeozoic Cape River Metamorphics, Tasmanides of north Queensland: evaluation of the roles of convergent and extensional tectonics: Australian Journal of Earth Sciences, v. 52, pp. 261-277.

Fergusson, C.L., Henderson, R.A., Fanning, C.M. and Withnall, I.W., 2007a, Detrital zircon ages in Neoproterozoic to Ordovician siliciclastic rocks, northeastern Australia: implications for the tectonic history of the East Gondwana continental margin: Journal of the Geological Society, v. 163, pp. $1-11$.

Fergusson, C.L., Henderson, R.A., Withnall, I.W., Fanning, C.M., Phillips, D. and Lewthwaite, K.L., 2007b, Structural, metamorphic and geochronological constrains on alternating compression and extension in the Early Palaeozoic Gondwana Pacific margin, northeast Australia: Tectonics, v. 26, pp. 1-20.

Fergusson, C.L., Henderson, R.A., Withnall, I.W. and Fanning, C.M., 2007c, Structural history of the Greenvale Province, north Queensland: Early Palaeozoic extension and convergence on the Pacific margin of Gondwana: Australian Journal of Earth Sciences, v. 54, pp. 573-595.

Foster, D.A. and Gray, D.R., 2000, Evolution and structure of the Lachlan Fold Belt (Orogen) of eastern Australia: Annual Review of Earth and Planetary Sciences v. 28, 47-80.

Gibson, G.M., Rubenach, M.J., Neumann, N.L., Southgate P.N. and Hutton, L.J., 2008, Syn- and post-extensional tectonic activity in the Paleoproterozoic sequences of Broken Hill, Mount Isa and its bearing on the reconstructions of Rodinia: Precambrian Research, v. 166, pp. 350369.

Glen, R.A. 2005, The Tasmanides of eastern Australia, in Vaughan, A.P.M.,
Leat, P.T. and Pankhurst, R.J. (eds), Terrane processes at the margin of Australia: Geological Society of London, Special Publication 246, pp. 23-96.

Gunn, P.J., Milligan, P., Mackey, T., Liu, S., Murray, A., Maidment, D. and Harren, R., 1997, Geophysical mapping using the national airborne and gravity datasets: an example on Broken Hill: AGSO Journal of Australian Geology and Geophysics, v. 17, pp. 127-136.

Henderson, R.A., 1980, Structural outline and summary geological history for northeastern Australia, in Henderson, R.A. and Stephenson, P.J. (eds), The Geology and Geophysics of Northeastern Australia: Geological Society of Australia Inc., Queensland Division, Brisbane, pp. 1-26.

Henderson, R.A., 1984, Early Ordovician faunas from the Mount Windsor Subprovince, northeastern Queensland: Australasian Association of Palaeontologists, Memoirs, v. 1, pp. 145-175.

Henderson, R.A., 1986, Geology of the Mt Windsor Subprovince-a Lower Palaeozoic volcanosedimentary terrane in the northern Tasman Orogenic Zone. Australian Journal of Earth Sciences, v. 33, pp. 343-364.

Henderson, R.A., 1987, An oblique subduction and transform faulting model for the evolution of the Broken River Province, northern Tasman Orogenic Zone: Australian Journal of Earth Sciences, v. 34, pp. 237-249.

Henderson, R.A., Innes, B.M., Fergusson, C.L., Crawford A.J. and Withnall I.W., 2011, Collisional accretion of a Late Ordovician oceanic island arc, northern Tasman Orogenic Zone, Australia: Australian Journal of Earth Sciences, v. 58, pp. 1-19.

Hill, D., 1951, Geology, in Mack, D. (ed), Handbook for Queensland: Australian Association for the Advancement of Science, pp. 13-24.

Hoffman, P.F., 1991, Did the breakout of Laurentia turn Gondwanaland inside out? Science, v. 252, pp. 1409-1412.

Huston, D.L., 1990, The stratigraphic and structural setting of the Balcooma volcanogenic massive sulphide lenses, northern Queensland: Australian Journal of Earth Sciences, v. 37, pp. 423-440.

Hutton, L.J., Draper, J.J., Rienks, I.P., Withnall, I.W. and Knutson, J. 1997, Charters Towers Region, in Bain, J.H.C. and Draper, J.J. (eds), North Queensland Geology. Australian Geological Survey Organisation Bulletin 240/Queensland Geology 9, pp. 165-224.

Karlstrom, K.E., Ahall, K.-I., Harlan, S.S., Williams, M.L., McLelland, J., Geissman, J.W., 2001, Long-lived (1.8-1.0 Ga) convergent orogen in southern Laurentia, its extension to Australia and Baltica, and implications for refining Rodinia: Precambrian Research, v. 111, pp. 5-230.

Kemp, A.I.S., Hawkesworth, C.J., Collins, W.J., Gray, C.M. and Blevin, P.L., 2009, Isotopic evidence for rapid continental growth in an extensional accretionary orogen; the Tasmanides, eastern Australia: Earth and Planetary Science Letters, v. 284, pp. 455-466.

Korsch, R.J., Huston, D.L., Henderson, R.A., Blewett, R.S., Withnall, I.W., Fergusson, C.L., Collins, W.J., Saygin, E., Kositcin, N., Champion, D.C., Meixner, A.J., Chopping, R., Henson, P.A., Hutton, L.J., Wormals, R., Holzschuh, J. and Costelloe, R.D., Crustal architecture of North Queensland, Australia, and geodynamic implications, based on deep seismic reflection profiling: Tectonophysics (in press).

Lambeck, A., 2011, Basin analysis and the geochemical signature of Paleoproterozoic sedimentary successions in northern Australia: Constraints on basin development in respect to mineralisation and paleoreconstruction models: PhD thesis, School of Earth and Environmental Sciences, University of Adelaide (unpublished).

Mackenzie, D.E. and Wellman, P., 1997, Kennedy Province, in Bain, J.H.C. and Draper, J.J. (eds), North Queensland Geology: Australian Geological Survey Organisation Bulletin 240/Queensland Geology 9, pp 488-500.

Monecke, T., Gemmell, B.J. and Herzig, P.M., 2006, Geology and volcanic facies architecture of the Lower Ordovician Waterloo massive sulfide deposit, Australia: Economic Geology, v. 101, pp. 179-197.

Mortimer, M., Hauff, F. and Calvert, A.T., 2008, Continuation of the New England Orogen, Australia beneath the Queensland Plateau and Lord Howe Rise: Australian Journal of Earth Sciences, v. 55, pp. 195-209.

Neumann, N.L. and Kositcin N., 2011, New SHRIMP U-Pb zircon ages from north Queensland 2007-2010. Geoscience Australia, Record 2011/38.

Nishiya, T., Watanabe, T., Yokoyama, K. and Kuramoto, Y., 2003, New isotopic 
constraints on the age of the Halls Reward Metamorphics, North Queensland, Australia: Delamerian metamorphic ages and Grenville detrital zircons: Gondwana Research, v. 6, pp. 241-249.

Oversby, B.S. and Mackenzie, D.E.M., 1995, Geology of late Palaeozoic ignimbrites and associated rocks in the Georgetown Region, northeastern Queensland: Australian Geological Survey Organisation, Record 1994/ 20.

Scheibner, E. and Veevers, J.J., 2000, Tasman Fold Belt System, in Veevers, J.J. (ed), Billion-Year Earth History of Australia and Neighbours in Gondwanaland: GEMOC Press, Sydney, pp. 154-234.

Shaw, R.D., Fawckner, J.F. and Bultitude, R.J., 1987, The Palmerville Fault System: a major imbricate thrust system in the northeastern Tasmanides, north Queensland: Australian Journal of Earth Sciences, v. 34, pp. 69-93.

Sloan, T.R, Talent, J.A., Mawson, R., Simpson, A.J., Brock, G.A., Engelbretsen, M.J., Jell, J.S., Aung, A.K., Pfaffenritter, C., Trotter, J. and Withnall, I.W., 1995, Conodont data from Silurian-Middle Devonian carbonate fans, debris flows, allochthonous blocks and adjacent autochthonous platform margins: Broken River and Camel Creek areas, North Queensland, Australia: Courier Forschungsinstitute Senckenburg, v. 182, pp. 1-77.

Stolz, A.J., 1995, Geochemistry of the Mount Windsor Volcanics: Implication for the tectonic setting of Cambro-Ordovician volcanic hosted massive sulphide mineralization in northeastern Australia: Economic Geology, v. 90, pp. 1080-1097.

Talent, J.A., Mawson, R., Simpson, A.J. and Brock, G.A., 2002, Palaeozoics of NE Queensland: Broken River Region: Ordovician-Carboniferous of the Townsville hinterland: Broken River and Camel Creek regions, Burdekin and Clarke River basins: IPC2002 Field Excursion Guidebook, Macquarie University Centre for Ecostratigraphy and Palaeobiology,

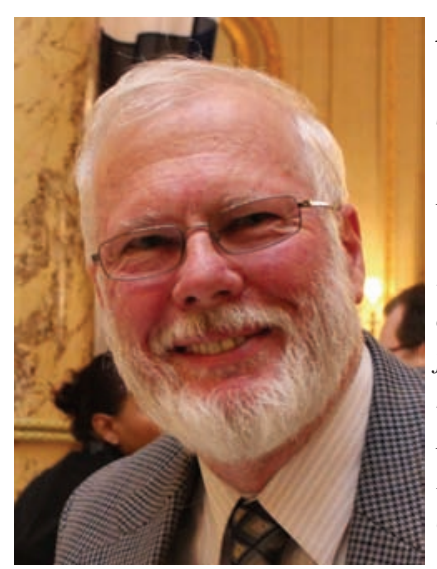

Ian Withnall has worked for the Geological Survey of Queensland since 1972 and is currently Geoscience Manger for Minerals. Most of his career has been in regional geological mapping and he also played a major role in developing the GSQ's computerised field data management system. His most recent research was in the Northwest Queensland Mineral Province but he has worked in most of the potentially mineralised regions of Queensland. He has contributed to research projects with geologists from various universities. In 2004, he was awarded the WR Browne Medal by the Geological Society of Australia for distinguished contributions to Australian geology.
Special Publication 1, Sydney, 82 pp.

Withnall, I.W., 1989, Precambrian and Palaeozoic Geology of the southeastern Georgetown Inlier: Queensland Department of Mines, Report 2, pp. 1102.

Withnall, I.W. and Lang, S.C., 1993, Geology of the Broken River Province, north Queensland: Queensland Geology 4.

Withnall, I.W., Black, L.P. and Harvey, K.J., 1991, Geology and geochronology of the Balcooma area - part of an early Palaeozoic magmatic belt in north Queensland: Australian Journal of Earth Sciences, v. 38, pp. 1529.

Withnall, I.W., Blake, P.R., Crouch, S.B.S., Tension-Woods, K., Grimes, K.G., Hayward, M.A., Lam, J.S., Garrad, P. and Rees, I.D., 1995, Geology of the southern part of the Anakie Inlier, central Queensland: Queensland Geology, 7.

Withnall, I.W., Mackenzie, D.E., Denaro, T.J., Bain, J.H.C., Oversby, B.S., Knutson, J., Donchak, P.J.T., Champion, D.C., Wellman, P., Cruikshank, B.I., Sun, S-.S. and Pain, C.F., 1997, Georgetown Region, in Bain, J.H.C. and Draper, J.J. (eds), North Queensland Geology: Australian Geological Survey Organisation Bulletin 240/Queensland Geology 9, pp. 19-116.

Withnall, I.W., Hutton, L.J., Bultitude, R.J., von Gnielinski, F.E. and Rienks, I.P., 2009, Geology of the Auburn Arch, Southern Connors Arch and adjacent parts of the Bowen Basin and Yarrol Province, Central Queensland: Queensland Geology 12.

Zucchetto, R.G., Henderson, R.A., Davis, B.K. and Wysoczanski, R., 1999, Age constraints on deformation of the eastern Hodgkinson Province, north Queensland: New perspectives on the evolution of the northern Tasman Orogenic Zone: Australian Journal of Earth Sciences, v. 46, pp. 105114.

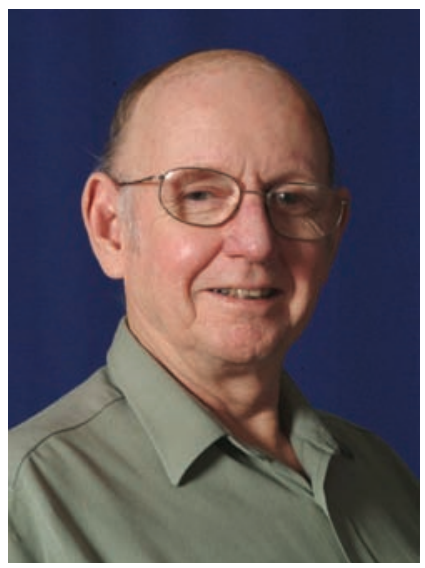

Bob Henderson has extensively investigated the Phanerozoic regional geology and tectonics of Queensland over a forty year period, with interests spanning both tectonised terranes within orogenic belts and little deformed cover basins. He also has contributed to knowledge of Australian Early Palaeozoic and Cretaceous invertebrate paleontology and its bearing on biostrati-graphy and the understanding of past environments. He is currently an Emeritus Professor of Earth Sciences at James Cook University and served a term as the President of the Geological Society of Australia in 19982000. 